\title{
INTERIORIZATION OF EDUCATIONAL NORMS AND VALUES AS A COMPOSITION OF FORMATION OF PROFESSIONAL QUALITIES IN HIGHER EDUCATION SYSTEM
}

\author{
Hanhal Artur ${ }^{1}$ \\ Biloshytskyi Volodymyr ${ }^{2}$
}

DOI: https://doi.org/10.30525/978-9934-571-89-3_48

The current state of the problems of the effectiveness of Ukrainian education reflects the contradiction between the growing demands of society on the morality and human intellect and the actual level of alertness of graduates of higher educational institutions. Under such conditions, the search for new approaches to improving the efficiency of the educational process with the focus on quality change is of fundamental importance.

To a certain extent, the issue of internalization is already traditional for domestic and foreign science. In the classical period of sociology and philosophy, the problem of internalization of the elements of social reality was considered by E. Durkheim, J. Piaget, L. Pento, N. Sardzhveladze. In Emile Durkheim (1995) work was presented as internalization process when the child borrows from the concept of social consciousness, action category, which then form the structure of his personal views.

Louis Pento (2001) studied the problems of internalizing those foundations that allow individuals to equally understand social reality. These foundations, becoming mental and deep, appear, in his view, as the relationship of the individual to himself, as part of a particular group or society as a whole.

Nodar Sardzhveladze (1989) considered adaptive function of individualization of social norms and values. Adapting to their social status and acceptance of certain social roles associated with the formation of a sense of belonging to a particular

\footnotetext{
${ }^{1}$ National Technical University of Ukraine

"Igor Sikorsky Kyiv Polytechnic Institute", Ukraine

2 National Technical University of Ukraine

"Igor Sikorsky Kyiv Polytechnic Institute", Ukraine 
community (national, professional, age etc) and belonging to it as to some collective body, characterized by specific means of self-preservation and self-support (traditions, rituals, stereotypes and patterns of behavior and so on). Thus, an individual becomes involved in a particular culture or subculture.

Important aspect of internalization of educational norms in students is the internalization of socially significant values. In the context of research of value orientations, the definition of personality is so: a personality is the individual existence of social relations, which is formed through the internalizations of socially significant values, through the assimilation of social norms and attitudes.

Social processes are influenced not only by the dominant hierarchy of values in society, but also by the way of appropriating the values of the individual. Methods of internalization of values show the nature of the social action of the individual. An analysis of such methods reveals not only that the individual wants to declare, as he understands reality, but also the real basis of his social action: he carries it either on his own, on the basis of the reflection of the social situation and the principles of life he has developed, or independently, but influenced the environment imposed by the society of values.

Values are specific social and psychological definitions of the objects of the surrounding world, which show their positive or negative significance for a person and society. The specificity of value orientations lies in the fact that they function not only as means of rationalization of behavior, their action extends not only to higher structures of consciousness, but also to those which are simply referred to as subconscious structures. Values are most stable element of social the sphere of society.

It is obvious that the beginning of studying at a high school for a student is a situation new, unfamiliar and, from a socio-pedagogical point of view, potentially threatening. Actualization of this potential threat may occur in the future, for example, academic failure, bad relations in the student group and, as a result, the destruction of certain illusions, self-esteem, frustration and, above all, loss of interest in learning.

The desire to understand oneself and its peculiarities, the desire to compare oneself with others and to assess their qualities give rise to increased sensitivity to the assessment of the personal qualities of the first year student, his behavior, his attitude toward him in general. Therefore, the curator, teachers, practical psychologist and social teacher in their educational work should take into account the psychological and physiological features of freshmen students, the value of self-esteem of the student in the development of communication, morality, the degree of educational and non-educational activity (Boiko, 2002).

Self-development plays an important role in the formation of the student's personality. The development itself serves as a kind of social and pedagogical factor in the successful adaptation of freshmen to the conditions of study in a higher education institution. Personality and surrounding its social environment connects the conventional consciousness. Its content is typical and traditional for a certain society or a certain community of norms, values, social roles, mediated through a system of 
meanings. As an image and a picture of the world, the conventional consciousness may be inadequate to new circumstances and the cause of inadequacy (Boiko, 2002).

The study of the effectiveness of the process of social adaptation of freshmen students to the conditions of education in higher educational institutions showed that educational, educational and spill-over can be attributed to the basic functions of social adaptation of freshmen students to the conditions of studying in higher educational institutions.

Given the scientific and methodological and development with identity problems of education of students, it should be noted the relevance of an approach of classic the in identifying key steps to support teaching first-year students in the process of social adaptation to training in higher education institution (Stepanov, 2005), which allows for concurrent processes and internalization.

At the first stage - signaling - the teacher records signals about the presence of a student-first-year student problems that he has.

At the second stage - contact - the teacher determines the emotional and psychological state of the student-first-year student, his readiness for conversation, provides the emotional and positive mood of the student-freshman to the conversation.

At the third stage - diagnostic - the teacher organizes a conversation with the student-first-year student, makes a diagnosis of his condition, finds out the causes of the problem that arose from the student-first-year student.

At the fourth stage - projective - the teacher helps the first-year student find a constructive solution to the problem.

At the fifth stage - active - the first-year student should follow the planned action plan for solving the problem, and the teacher carries out only the pedagogical support of the student's efforts.

At the last stage, a productive-analytical one, a teacher with a freshman student discusses the successes and failures of the educational work conducted, states the fact of solving the problem or other plan of action (Stepanov, 2005).

An important regularity of the process of social adaptation of students in the field of higher education is the goals of education and training. Targeted pedagogical guides will be perceived by individual subjects, student groups and pedagogical teams only when they are associated with their interests, needs and aspirations, they will be concerned. This is the most important pedagogical condition of the positive effect of the natural relationship between the pedagogical influence and the active educational activity of students, which contributes to their general and professional development, the formation of student collectives; A very important pedagogical regularity is the constantly existing need to create conditions for the successful transformation of external influences into the students' internal position. Each student has his own, individual acquired experience, his own individual peculiarities of emotions, will, cognitive processes, motives, needs, etc. Because of these internal factors and the transformation of external influence occurs. It is clear that this transformation is individual - in one it happens so, in another - differently. That is why, while retaining this individuality, we must develop everything positive in it; It 
was established that the degree of development of the activity and independence of students and student groups is largely influenced by the style of teaching leadership of teachers, the level of their pedagogical skills. There, of course, there is a logical connection.

Thus, the main strategic direction of the development of higher education should lie in the plane of solving the problem of the development of not only the personality of the student, but also the teacher, and the process of technological development of learning, should be considered as providing an acceleration of adaptation of subjects and objects of study, with this process of internalization of their educational and social norms and values must be constantly improved.

\section{References:}

1. Boiko I. I. (2002). Sotsialno-psykholohichna adaptatsiia pidlitka do novykh umov navchannia [Socio-psychological adaptation of a teenager to new learning conditions]. (in Ukrainian)

2. Emile Durkheim, Gofman A. B. (Ed.) (1995). Sotsiologiya. Ee predmet, metod i naznachenie [Sociology. Its subject, method and purpose], Moscow: Kanon. (in Russian)

3. Remi Lenoir, Patrick Champagne, Dominique Merllie, Louis Pinto (2001). Nachala prakticheskoy sotsiologii [Beginning of practical sociology], Saint Petersburg: Aletheia. (in Russian)

4. Sardzhveladze N.I. (1989). Lichnost' i ee vzaimodeystvie s sotsial'noy sredoy [Personality and its interaction with the social environment] Tbilisi: Metsnyereba. (in Russian)

5. Stepanov E. N. (Ed.) (2005). Vospitanie individual'nosti. Uchebno-metodicheskoe posobie [Education of individuality: Textbook], Moscow: TT Sfera. (in Russian) 